\title{
OCENA WYTRZYMAŁOŚCI NA ŚCINANIE BEZ ODPLYWU WYBRANEGO GRUNTU ORGANICZNEGO NA PODSTAWIE BADAŃ SONDĄ FVT
}

\begin{abstract}
W niniejszym opracowaniu zaprezentowano procedury badań i wyznaczanie wytrzymałości na ścinanie w warunkach bez odpływu dla wybranego gruntu organicznego zalegającego na terenie Rzeszowa. Wykorzystano w tym celu wyniki badań przeprowadzonych za pomocą sondy obrotowej FVT warunkach ,in situ" oraz laboratoryjnych. Analiza wyników wykazała, że wartości wytrzymałości na ścinanie wyprowadzone bezpośrednio z pomiarów oporu podczas ścinania gruntu organicznego są zawyżone w odniesieniu do rezultatów alternatywnych badań laboratoryjnych. Dokonano przeglądu literatury i przeanalizowano problematykę związaną z koniecznością korygowania otrzymanych wyników do celów projektowania geotechnicznego za pomocą współczynnika poprawkowego $\mu$. Przedstawiono własną propozycję wartości współczynnika poprawkowego, właściwą wyłącznie dla badanego gruntu organicznego. Skorygowaną wartość wytrzymałości na ścinanie w warunkach bez odpływu porównano $\mathrm{z}$ alternatywnymi propozycjami innych badaczy.
\end{abstract}

Słowa kluczowe: grunty organiczne, wytrzymałość w warunkach bez odpływu, sonda FVT

\section{Wprowadzenie}

Rozpoznanie geotechniczne podłoża, w którym występują grunty organiczne jest procesem bardziej skomplikowanym i pracochłonnym niż w przypadku typowych gruntów mineralnych [24]. Istnieje wiele algorytmów umożliwiających szacowanie parametrów geotechnicznych na podstawie wyników sondowań, lecz w przypadku gruntów organicznych bardzo często występują wątpliwości związane $\mathrm{z}$ doborem właściwych współczynników poprawkowych do formuł, prezentowanych w aktualnych normatywach [21]. Problem ten dotyczy nie tylko polskich realiów, gdyż nie jest definitywnie uregulowany również w skali globalnej. O kluczowym znaczeniu współczynników poprawkowych

\footnotetext{
${ }^{1}$ Grzegorz Straż, Politechnika Rzeszowska im. Ignacego Łukasiewicza, Zakład Geodezji i Geotechniki im. Kaspra Weigla, ul. Poznańska 2, 35-959 Rzeszów, Tel.178651006, e-mail: gstraz@prz.edu.pl.
} 
świadczy fakt, iż one decydują o ostatecznej, przyjmowanej do obliczeń inżynierskich wartości wyznaczanego parametru wytrzymałościowego. Mimo, że współczesne polowe metody rozpoznania podłoża są coraz dokładniejsze i generują precyzyjne wartości parametrów pomierzonych to jednak w pełni nie odzwierciedlają rzeczywistych warunków panujących w podłożu. Zasadnym wydaje się gromadzenie wyników badań, grupowanie ich nie tylko pod względem rodzaju gruntu, ale również miejsce jego zlokalizowania, sukcesywnie prowadząc do rejonizacji badań [6]. Na etapie gromadzenia danych wyniki badań gruntów w warunkach ,in situ” powinny być równolegle weryfikowane alternatywnymi metodami laboratoryjnymi. Niezbędne jest również każdorazowe oznaczanie parametrów uznanych za wiodące dla danego rodzaju gruntu, takich jak: wilgotność naturalna, gęstość objętościowa czy zawartość części organicznych, stanowiących układ odniesienia na etapie poszukiwania korelacji z pomiędzy parametrami wytrzymałościowymi. W niniejszej pracy, na przykładzie wyznaczania wytrzymałości na ścinanie bez odpływu za pomocą sondy obrotowej FVT (stara polska nazwa: PSO) w warunkach ,in situ”, zaprezentowano trudności związane z wyprowadzaniem parametrów wytrzymałościowych dla podłoża zbudowanego z gruntów organicznych.

\section{Rozpoznanie podłoża sondą FVT}

Celem badania podłoża sondą obrotową FVT jest pomiar oporu, jaki stawia grunt obracającej się końcówce krzyżakowej. Na podstawie pomierzonego w trybie ciągłym momentu ścinającego, istnieje możliwość wyprowadzenia wartości wytrzymałości na ścinanie $w$ warunkach bez odpływu oraz określenie wrażliwości strukturalnej gruntu [21]. Praktyka krajowa i światowa potwierdziła szczególną przydatność sondy obrotowej między innymi do badania różnego rodzaju gruntów słabych, w tym organicznych. Pomiary oporu za pomocą sondy FVT mogą być prowadzone w kilku wariantach, uwzględniając różne metody instalacji penetrometru $\mathrm{w}$ gruncie czy sposoby eliminowania wpływu tarcia żerdzi na ostateczne wynik pomiaru [8]. Szczegóły dotyczące budowy sondy i mechanizmu samego procesu ścinania zostały wielokrotnie opisane w instrukcjach, normach oraz literaturze, dlatego $\mathrm{w}$ pracy skupiono się przede wszystkim na metodyce interpretacji wyników badań.

Wieloletnia praktyka wykazała, że wytrzymałość na ścinanie obliczona na podstawie pomierzonych oporów ścinania $\left(\mathrm{c}_{\mathrm{fv}}\right) \mathrm{z}$ reguły jest zawyżona $\mathrm{w}$ stosunku do wytrzymałości rzeczywistej gruntu $\left(\mathrm{c}_{\mathrm{u}}\right)$, dlatego powinna być skorygowana współczynnikiem poprawkowym $(\mu)$ co znalazło również odzwierciedlenie w wytycznych normowych [21] dotyczących interpretacji wyników sondą obrotową FVT:

$$
c_{u}=\mu \quad c_{f v}
$$

gdzie: $c_{u}$ - wytrzymałość gruntu na ścinanie w warunkach bez odpływu $[\mathrm{kPa}]$, 
$\mathrm{c}_{\mathrm{fv}}$ - wytrzymałość gruntu na ścinanie określona na podstawie pomiarów sondą FVT [kPa],

$\mu$ - współczynnik poprawkowy [-].

Wartość współczynnika poprawkowego najczęściej uzależniana jest od wskaźnika plastyczności, granicy płynności, efektywnego naprężenia pionowego lub stopnia konsolidacji gruntu. Na przestrzeni prowadzonych przez lata badań, wielu badaczy w sposób empiryczny ustaliło również stałe wartości współczynników poprawkowych, przyporządkowanych do konkretnego rodzaju gruntu o znanych właściwościach. Powszechnie znaną metodą jest wyznaczanie współczynnika poprawkowego na podstawie granic Atterberga. Procedurę tę trudno zastosować dla gruntów organicznych, gdyż prezentowane w Eurokodzie 7 przykłady dotyczą wyłącznie gruntu mineralnego - iłu, a w zakresie określania współczynnika poprawkowego dla innych gruntów normatyw generalnie odwołuje się do lokalnych doświadczeń, które z reguły nie są powszechnie dostępne i znane.

Oprócz standardowej wersji sondy obrotowej FVT, istnieje również jej bardziej zaawansowana pod względem budowy wersja, znana pod nazwą: piezosonda obrotowa PZO-1, która posiada wbudowany moduł umożliwiający pomiar ciśnienia wody w porach gruntu, co pozwala na szacowanie parametrów efektywnych podłoża [9].

\section{Opis badań podłoża organicznego}

Warstwę gruntów organicznych o miąższości około 1,0m, której strop ustalono na głębokości 0,6m p.p.t., zlokalizowano we wschodniej części miasta Rzeszowa. Grunty organiczne będące przedmiotem badań, sklasyfikowano jako namuły gliniaste $(\mathrm{Nmg})$, zgodnie $\mathrm{z}$ nieaktualną, lecz nadal stosowaną polską normą [19]. Można domniemywać, że w kontekście najnowszych wytycznych w zakresie klasyfikowania gruntów [22, 23] namułom odpowiadać powinny grunty organiczne (np. siOr, clOr, saOr) albo grunty mineralne zawierające substancje organiczne (np. orSi, orCl, orSa). Na chwilę obecną brakuje szczegółowych, usankcjonowanych w normatywach ustaleń w tym zakresie. Charakterystyczne właściwości badanego gruntu organicznego zaprezentowano w tabeli 1.

Tabela 1. Cechy charakterystyczne wybranego gruntu organicznego z Rzeszowa [25]

Table 1. Index properties of selected organic soil from Rzeszow [25]

\begin{tabular}{|c|c|c|c|c|c|c|}
\hline \multirow{2}{*}{$\begin{array}{c}\text { Uziar- } \\
\text { nienie }\end{array}$} & $\begin{array}{c}\text { Zawartość } \\
\text { części orga- } \\
\text { nicznych }\end{array}$ & $\begin{array}{c}\text { Wilgotność } \\
\text { naturalna }\end{array}$ & $\begin{array}{c}\text { Uśredniony } \\
\text { wskaźnik } \\
\text { plastyczności }\end{array}$ & $\begin{array}{c}\text { Ciężar obję- } \\
\text { tościowy }\end{array}$ & $\begin{array}{c}\text { Granica } \\
\text { płynności }\end{array}$ & $\begin{array}{c}\text { Granica } \\
\text { plastyczno- } \\
\text { ści }\end{array}$ \\
\hline \multirow{2}{*}{$\mathrm{siCl}$} & $\mathrm{I}_{\mathrm{om}}[\%]$ & $\mathrm{W}[\%]$ & PI [\%] & $\gamma\left[\mathrm{kNm}^{-3}\right]$ & $\mathrm{LL}[\%]$ & $\mathrm{PL}[\%]$ \\
\cline { 2 - 4 } (or) & 10,6 & 36,8 & \multirow{2}{*}{51,9} & 17,0 & 78,8 & 26,9 \\
\cline { 2 - 5 } \cline { 5 - 7 } & $9,7-11,8$ & $33,3-39,9$ & & $16,0-17,8$ & $75,0-84,5$ & $25,8-28,7$ \\
\hline
\end{tabular}


W środku wyodrębnionej warstwy wykonano 10 badań sondą FVT, ścinając grunt, poprzez obrót krzyżaka sondy o pełny kąt $360^{\circ}$. Jednocześnie z głębokości na jakiej prowadzono badania sondą FVT, pozyskano odpowiedniej jakości próbki o nienaruszonej strukturze, które poddano alternatywnym testom laboratoryjnym. Wykorzystano $\mathrm{w}$ tym celu: aparat bezpośredniego ścinania, aparat trójosiowego ściskania oraz laboratoryjny zestaw badawczy przystosowany do badań za pomocą sondy obrotowej FVT [25]. Badania sondą FVT w warunkach laboratoryjnych oraz ,in situ” wykonano końcówką krzyżakową o wymiarach: $\mathrm{D}=60 \mathrm{~mm}$ oraz $\mathrm{H}=120 \mathrm{~mm}$. Określono maksymalną i rezydualną wytrzymałość na ścinanie „bez odpływu” oraz wrażliwość strukturalną gruntu. Analiza wyników wykazała, że wszystkie wskaźniki wrażliwości strukturalnej gruntu (IR) nie przekraczały wartości 4,0 co świadczy o tym, że badany grunt nie jest wrażliwy na zniszczenie struktury [20].

W tabeli 2. zaprezentowano wartości wytrzymałość na ścinanie bez odpływu, które są wartościami wyprowadzonymi w oparciu o wyniki badań bezpośrednich za pomocą sondy FVT oraz obliczone w oparciu o ustalone w warunkach laboratoryjnych parametry wytrzymałościowe gruntu organicznego: kąt tarcia wewnętrznego $\phi$ oraz spójność $c$. Wyniki badań potwierdziły fakt zawyżania wartości wytrzymałości na ścinanie bez odpływu obliczonej na podstawie pomierzonych oporów ścinania, dlatego na dalszym etapie badań podjęto próbę ustalenia wartości współczynnika poprawkowego, właściwego dla gruntu organicznego poddanego badaniom. Uśrednione wartości wytrzymałości na ścinanie z badań w warunkach ,in situ” oraz w laboratoryjnym zestawie badawczym [25] wynosiły odpowiednio $60,3 \mathrm{kPa}$ oraz $56,5 \mathrm{kPa}$. W celu wyznaczenia współczynnika poprawkowego wyniki badań polowych odniesiono do rezultatów badań we-

Tabela 2. Wartości wytrzymałości na ścinanie bez odpływu dla gruntu organicznego [25]

Table 2. Undrained shear strength for local organic soil [25]

\begin{tabular}{|c|c|c|c|c|c|}
\hline Rodzaj badań & $\begin{array}{c}\begin{array}{c}\text { Liczba } \\
\text { próbek }\end{array} \\
\text { N [-] }\end{array}$ & \multicolumn{2}{|c|}{$\begin{array}{c}\text { Zakres wartości wytrzy- } \\
\text { małości na ścinanie bez } \\
\text { odpływu } \\
\text { cfv }[\mathrm{kPa}]\end{array}$} & $\begin{array}{c}\text { Uśredniona wy- } \\
\text { trzymałość na } \\
\text { ścinanie bez } \\
\text { odpływu } \\
\text { cfv }[\mathrm{kPa}] \\
\end{array}$ & $\begin{array}{c}\text { Proponowany } \\
\text { współczynnik } \\
\text { korekcyjny } \\
\mu=c_{\mathrm{i}} / \mathrm{c}_{\mathrm{fv}}[-]\end{array}$ \\
\hline $\mathrm{FVT}$ - bad. polowe & 10 & \multicolumn{2}{|c|}{55,8 to 66,4} & 60,30 & 1,00 \\
\hline $\begin{array}{c}\text { FVT - zestaw labo- } \\
\text { ratoryjny }\end{array}$ & 6 & \multicolumn{2}{|c|}{55,2 to 57,9} & 56,50 & 0,94 \\
\hline \multirow{2}{*}{\multicolumn{2}{|c|}{$\begin{array}{l}\text { Laboratoryjne testy weryfiku- } \\
\text { jące }\end{array}$}} & \multicolumn{2}{|c|}{$\begin{array}{l}\text { Parametry wytrzymałościo- } \\
\text { we }\end{array}$} & \multirow[t]{2}{*}{$\tau_{i}=\sigma * \operatorname{tg} \phi_{i}+c_{i}$} & \multirow[t]{2}{*}{-} \\
\hline & & $\phi_{\mathrm{i}}[\mathrm{deg}]$ & $\mathrm{c}_{\mathrm{i}}[\mathrm{kPa}]$ & & \\
\hline $\begin{array}{l}\text { Aparat bezp. ścina- } \\
\text { nia }\end{array}$ & 364 & $13,3-25,3$ & $23,3-43,7$ & 40,60 & 0,67 \\
\hline $\begin{array}{c}\text { Aparat trójosiwego } \\
\text { ściskania }\end{array}$ & 32 & $0-3,41$ & $38,2-50,2$ & 45,30 & 0,75 \\
\hline
\end{tabular}


ryfikujących, tzn. 40,6 kPa uzyskanych dla aparatu bezpośredniego ścinania oraz 45,3 kPa dla aparatu trójosiowego ściskania. Wielkość określonych tym sposobem współczynników poprawkowych wynosiła odpowiednio 0,67 oraz 0,75 . W celu dalszych analiz i porównań przyjęto najmniejszą, a więc bezpieczniejszą wartość współczynnika poprawkowego $\mu$.

\section{Metody określania współczynnika poprawkowego}

Materiały źródłowe nawiązujące do problematyki rozpoznania podłoża za pomocą sondy FVT oraz interpretacji wyników badań są bardzo obszerne. W pracy zaprezentowano wybrane przykłady przyjmowania wartości współczynnika poprawkowego $\mu$. Na rysunku 1. zaprezentowano zależności autorstwa różnych badaczy pozwalające na wybór współczynnika korekcyjnego w oparciu o wskaźnik plastyczności lub granicę płynności. Wybrane, najczęściej stosowane procedury doboru wartości współczynnika poprawkowego do obliczania wytrzymałości na ścinanie $\mathrm{w}$ warunkach bez odpływu na podstawie wartości pomierzonych za pomocą sondy obrotowej FVT w warunkach ,in situ” zestawiono w tabeli 3. (str. 98). Mimo, że opracowanie dotyczy wybranego gruntu organicznego w zestawieniu zaprezentowano sposoby określania współczynnika korekcyjnego opracowane dla różnych rodzajów gruntów. Podyktowane było to faktem, iż związane z tematyką dane dotyczące gruntów organicznych są bardzo

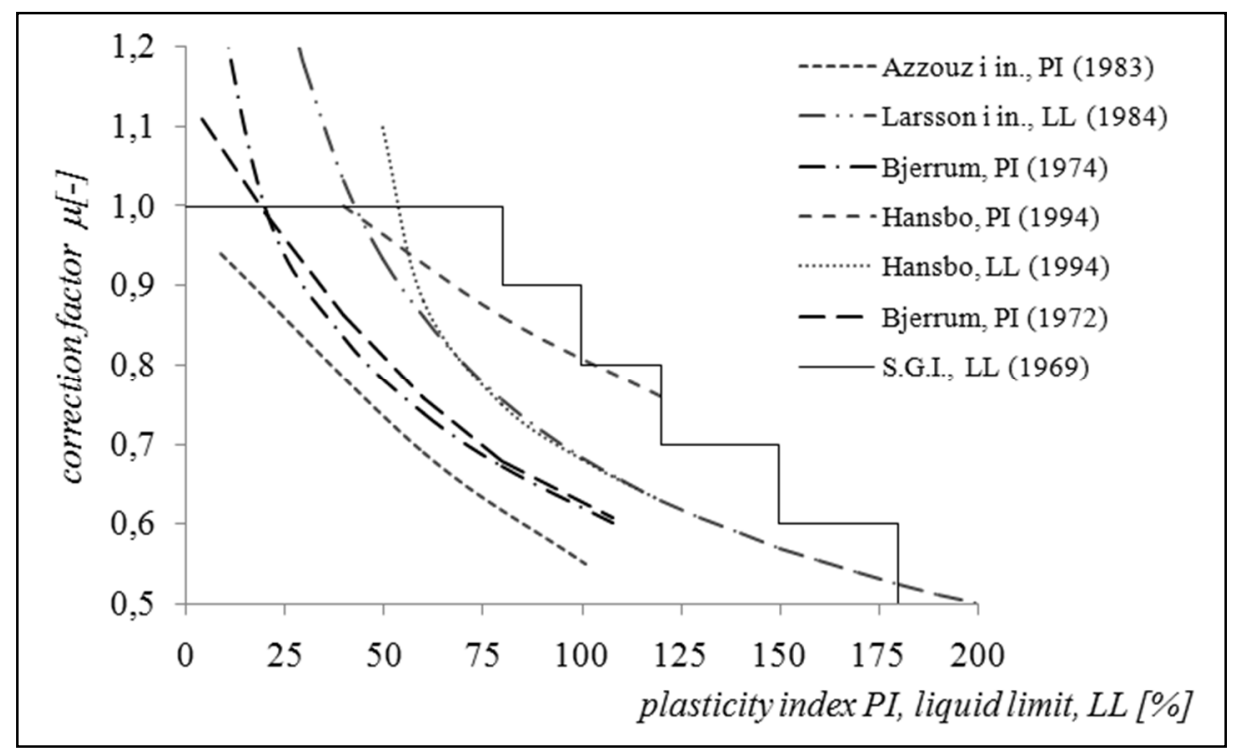

Rys. 1. Wartości współczynników korekcyjnych w zależności od granicy płynności (LL) i wskaźnika plastyczności (IP) w odniesieniu do propozycji różnych badaczy

Fig. 1. Values of correction factors according to the liquid limit (LL) and plasticity index (IP) with respect to the proposals of various researches 
ograniczone, a w niektórych metodach rodzaj gruntu nawet nie jest brany pod uwagę. Często natomiast uwzględniane są parametry charakterystyczne, takie jak: granica płynności (LL), zawartość części organicznych $\left(\mathrm{I}_{\mathrm{om}}\right)$, wskaźnik plastyczności (PI) czy prekonsolidacji (OCR). Niektóre współczynniki korekcyjne zostały określone w sposób empiryczny na stałym poziomie, właściwym dla konkretnego rodzaju gruntu o znanych właściwościach.

Propozycje korygowania wytrzymałości na ścinanie z badań sondą FVT na podstawie wykresów opierają się głównie na znajomości granicy Atterberga płynności lub wskaźnika plastyczności badanego gruntu. Najczęściej przywoływane $\mathrm{w}$ materiałach literaturowych, również historyczne, sposoby interpretacji graficznej zebrano i zaprezentowano na wykresie zbiorczym (rys. 1.). Jedną z pierwszych metod opierającą się na znajomości granicy płynności zaprezentował Szwedzki Instytut Geotechniczny w 1969r. [10]. Kolejne propozycje, autorstwa Bjerrum'a [2, 3] oraz Azzuoz'a i in. [1], opracowane zostały dla nieskonsolidowanych, mało plastycznych iłów, wykorzystując do korygowania znajomość wskaźnika plastyczności. W polskiej normie do badań polowych [20] zamieszczono inne rozwiązanie Bierrum'a [8], które pozwala na określenie współczynnika korekcyjnego zarówno na podstawie wskaźnika plastyczności, jaki i granicy płynności. Larrson z zespołem [14] dla normalnie skonsolidowanych i nieco prekonsolidowanych iłów, zaproponował zależność pomiędzy wartością współczynnika poprawkowego a granicą płynności, której używanie zaleca Eurokod 7 [21]. W iłach o stopniu prekonsolidowania większym niż 1,3 normatyw ten odwołuje się do opublikowanego przez Larssona i Ahnberga [15], rozwiązania zależnego od wartości stopnia prekonsolidowania, natomiast, gdy stopień prekonsolidacji iłów nie został ustalony, zaleca oszacować wartość współczynnika poprawkowego według wzoru Hansbo [7]. W przypadku torfów współczynnik może być przyjmowany w zależności od stopnia rozkładu $\mathrm{R}$ [21]. Interesująca jest propozycja Chandlera [4] opracowana dla pyłów i iłów, wprowadzając dwustopniowe korygowanie wytrzymałości na ścinanie w celu oddzielenia efektu odkształcenia $\mu_{\mathrm{R}} \mathrm{i}$ anizotropii $\mu_{\mathrm{A}}$. Chandler oszacował zależność pomiędzy współczynnikiem poprawkowym a wskaźnikiem plastyczności, efektem odkształcenia uwzględniając czas zniszczenia. Morris i Williams [17] uwzględnili niezależne korelacje pomiędzy współczynnikiem poprawkowym a wskaźnikiem plastyczności i granicą płynności, podczas gdy Kulhawy [11] wziął pod uwagę tylko wskaźnik plastyczności. W literaturze znaleziono również przykłady stałych współczynników poprawkowych. Ladd i Foott [12] dla prekonsolidowanych iłów warwowych zaproponowali wartość współczynnika 0,85 $\pm 0,5$. Dla gruntów organicznych, nie wyłączając torfów, Terzaghi z zespołem [27] ustalił wartość 0,85. Swoje propozycje przedstawili także: Edil [5] od 0,40 do 0,55 oraz Mesri i Ajlouni [16] wartość 0,50, nie podając jednak szczegółów w przypadku jakich gruntów można je stosować. Propozycje dotyczące wielkości współczynnika poprawkowego w zakresie 0,45-0,60 dla polskich gruntów organicznych zaprezentował między innymi Tarnawski [26]. 


\section{Szacowanie wytrzymałości na ścinanie bez odpływu}

Szacowanie wytrzymałości na ścinanie w warunkach bez odpływu za pomocą sondy krzyżakowej FVT polega na określeniu wytrzymałości na ścianie gruntu w warunkach ,,in situ” a następnie skorygowaniu wyniku za pomocą właściwego współczynnika poprawkowego $\mu$. Z uwagi na cały szereg istniejących sposobów dotyczących ustalania wartości współczynnika korekcyjnego w tabeli 3 wybrano oraz zestawiono w sposób chronologiczny najczęściej stosowane metody jego określania, opracowane przez różnych badaczy. Zaprezentowano również wyniki szacowania wytrzymałości na ścinanie bez odpływu, ustalone z wykorzystaniem przywoływanych w tabeli współczynników.

Analizując wyniki obliczeń stwierdzono, że charakteryzują się ogromnym zróżnicowaniem, które w poważnym stopniu utrudnia ich porównanie i wybór wartości optymalnej. Dodatkowo sytuację komplikował fakt, iż w niektórych przypadkach autorzy nie podają szczegółowych informacji dla jakich gruntów zostały określone przywoływane procedury określenia współczynnika $\mu$, a tym samym czy można je stosować dla gruntów organicznych czy nie. Zaprezentowane w celu porównania w tabeli 3. wartości współczynników zostały ustalone na podstawie zależności od różnych parametrów geotechnicznych lub przyjęte jako wartości stałe, ustalone w sposób empiryczny dla różnych rodzajów gruntów o znanych właściwościach.

Analiza wyników szacowania wytrzymałości na ścinanie w warunkach bez odpływu przedstawionych $\mathrm{w}$ tabeli 3 wykazała, że zakres proponowanych współczynników poprawkowych jest bardzo szeroki i obejmuje wartości od 0,40 do $0,92 \mathrm{z}$ wykluczeniem raczej historycznej propozycji Szwedzkiego Instytutu Geotechnicznego (1969), gdzie wartość współczynnika przyjęto równą 1,0. Graniczne wartości współczynników poprawkowych wygenerowały następujące wartości wytrzymałości na ścinanie w warunkach bez odpływu: minimalną, uzyskaną w oparciu o propozycję Edila [5] równą 24,12kPa oraz maksymalną, określoną według zaleceń Hansbo [8] wynoszącą 55,48kPa. Różnica pomiędzy nimi wynosi ponad $100 \%$, co stanowi poważny problem z inżynierskiego punktu widzenia, ponieważ obliczone na ich podstawie wartości nośności w warunkach bez odpływu dla tego samego gruntu mogą diametralnie różnić się od siebie.

Autor przeprowadził własne badania mające na celu ustalenie wartości współczynnika poprawkowego $\mu$ dla gruntu organicznego o zawartości części organicznych wynoszącej około $11 \%$ i znanych cechach fizycznych (Tab. 1.). $\mathrm{Z}$ analizy przeprowadzonych badań (Tab. 2.) wynika, że dla wybranego gruntu organicznego optymalna, bezpieczna wartość współczynnika poprawkowego to 0,67 . Wartość ta wpisuje się w przedstawione w tabeli 3. propozycje, a wytrzymałość na ścinanie bez odpływu obliczona z zastosowaniem ustalonego empirycznie współczynnika wynosi 43,42 $\mathrm{kPa}$. 
Tabela 3. Metody określania, zakres stosowalności, wartości współczynników poprawkowego oraz wartości wyprowadzone wytrzymałości na ścinanie wg wybranych źródeł

Table 3. Determination methods, range of applicability, values of correction factor and undrained shear strengths according to selected sources

\begin{tabular}{|c|c|c|c|c|c|}
\hline Lp. & Autorzy & $\begin{array}{l}\text { Metoda określania wspót- } \\
\text { czynnika poprawkowego }\end{array}$ & $\begin{array}{c}\text { Zakres } \\
\text { stosowalno- } \\
\text { ści }\end{array}$ & \begin{tabular}{|c|} 
Oszacowany \\
lub wybrany do \\
analizy wspót- \\
czynnik po- \\
prawkowy \\
$\mu[-]$ \\
\end{tabular} & \begin{tabular}{|c|} 
Wytrzyma- \\
lość na ścina- \\
nie w warun- \\
kach bez \\
odpływu \\
$c_{u}[\mathrm{kPa}]$ \\
\end{tabular} \\
\hline 1 & Hansbo [8] & $\left(\frac{0,43}{w_{L}}\right)^{0.45}\left(\frac{c_{f v}}{0,585 w_{L} \sigma_{v 0}^{\prime}}\right)^{-0,15}$ & iły & 0,41 & 24,72 \\
\hline 2 & S.I.G. [11] & $\begin{array}{c}\mu=f(L L)-\text { zgodnie } z \text { wykresem } \\
\text { (Rys. 1) }\end{array}$ & nieokreślone & 1,00 & 60,30 \\
\hline 3 & Bjerrum [2] & $\begin{array}{c}\mu=f(P I)-\text { zgodnie } \mathrm{z} \text { wykresem } \\
\text { (Rys.1) }\end{array}$ & iły & 0,78 & 47,03 \\
\hline 5 & Bjerrum [3] & $1,7-0,54 \log (\mathrm{PI})$ & nieokreślone & 0,84 & 50,65 \\
\hline 6 & $\begin{array}{c}\text { Ladd \& Foott } \\
{[13]}\end{array}$ & $0,85 \pm 0,05$ & iły & 0,80 & 48,24 \\
\hline 7 & $\begin{array}{c}\text { Azzuoz et al. } \\
{[1]}\end{array}$ & $\begin{array}{c}\mu=f(P I)-\text { zgodnie z wykresem } \\
\text { (Rys.1) }\end{array}$ & iły & 0,74 & 44,62 \\
\hline 8 & Chandler [4] & $\begin{array}{c}\mu_{\mathrm{R}}=1,05-b(P I)^{0,5} \\
\mathrm{~b}=0,015-0,0075 \log t_{f} \\
\mu_{\mathrm{A}}=0,5-1,0[\mathrm{C}]\end{array}$ & iły i pyły & - & - \\
\hline 9 & $\begin{array}{l}\text { Larson et } \\
\text { al.[16] }\end{array}$ & $\begin{array}{c}\left(\frac{0,43}{L L}\right)^{0,45} \mu=f(L L)-\text { zgodnie } \mathrm{z} \\
\text { rys. } 1 .\end{array}$ & iły & 0,76 & 45,83 \\
\hline 10 & $\begin{array}{c}\text { Tarnawski } \\
{[27]}\end{array}$ & $0,45-0,60$ & $\begin{array}{l}\text { grunty orga- } \\
\text { niczne }\end{array}$ & $0,45-0,60$ & $27,14-36,18$ \\
\hline 11 & Kulhawy [12] & $1,2-0,0243 \mathrm{PI}^{0,695}$ & nieokreślone & 0,84 & 50,65 \\
\hline 12 & \multirow{2}{*}{ Hansbo [9] } & $\begin{array}{c}\mu(\mathrm{LL})-\underset{\text { (Rys. })}{\text { zgodnie } \mathrm{z} \text { wykresem }} \\
\text { (Ry) }\end{array}$ & nieokreślone & 0,76 & 45,83 \\
\hline 13 & & $\begin{array}{c}\mu(\mathrm{PI}) \text { - zgodnie } \mathrm{z} \text { wykresem } \\
\text { (Rys.1) }\end{array}$ & nieokreślone & 0,92 & 55,48 \\
\hline 14 & \multirow{2}{*}{$\begin{array}{c}\text { Morris \& } \\
\text { Williams [19] }\end{array}$} & $1,18 \mathrm{e}^{-0,08 P \mathrm{PI}}+0,57$ & nieokreślone & 0,59 & 35,58 \\
\hline 15 & & $7,01 \mathrm{e}^{-0,08 \mathrm{LL}}+0,57$ & nieokreślone & 0,68 & 41,00 \\
\hline 16 & $\begin{array}{c}\text { Terzaghi et } \\
\text { al. [29] }\end{array}$ & 0,85 & $\begin{array}{l}\text { grunty orga- } \\
\text { niczne }\end{array}$ & 0,85 & 51,26 \\
\hline 17 & Edil [5] & \begin{tabular}{|c|}
$0,40-0,55$ \\
\end{tabular} & nieokreślone & $0,40-0,55$ & $24,12-33,17$ \\
\hline 18 & $\begin{array}{c}\text { Larrson \& } \\
\text { Ahnberg [15] }\end{array}$ & $\begin{array}{c}\mu_{\mathrm{LL}} \text { - zgodnie z wykresem (Rys.1) } \\
\mu_{\mathrm{OCR}}=(\mathrm{OCR} / 1,3)^{-0,15}\end{array}$ & iły o $R_{\mathrm{OC}} \geq 1.5$ & 0,71 & 42,81 \\
\hline 19 & $\begin{array}{c}\text { Mesri \& } \\
\text { Ajlouni [18] }\end{array}$ & 0,50 & nieokreślone & 0,50 & 30,15 \\
\hline 20 & \multirow{2}{*}{$\begin{array}{c}\text { Eurocode } 7 \\
{[23]}\end{array}$} & 0,65 & torf, $\mathrm{R}<30 \%$ & 0,65 & 39,20 \\
\hline 21 & & 0,80 & $\begin{array}{c}\text { torf, } \mathrm{R}<35-60 \\
\% \\
\end{array}$ & 0,80 & 48,24 \\
\hline 22 & Straż & 0,67 & $\begin{array}{c}\text { grunty organ- } \\
\text { iczne } \\
\mathrm{I}_{\mathrm{om}}=11 \% \\
\end{array}$ & 0,67 & 43,42 \\
\hline
\end{tabular}




\section{Podsumowanie}

Przeprowadzone w warunkach polowych i laboratoryjnych badania wybranej warstwy gruntu organicznego za pomocą sondy FVT, umożliwiły oszacowanie wytrzymałości na ścinanie w warunkach bez odpływu. Weryfikacja uzyskanych wyników, przeprowadzona za pomocą badań laboratoryjnych w aparacie bezpośredniego ścinania oraz trójosiowego ściskania wykazała, że są zawyżone i wymagają skorygowania. Porównano wyniki badań wytrzymałości na ścinanie dla analizowanego gruntu organicznego (tab. 2.) oraz wyznaczono własną wartość współczynnika poprawkowego. W tabeli 3 . zaprezentowano wyprowadzone wartości wytrzymałości na ścinanie w warunkach bez odpływu z zastosowaniem współczynników poprawkowych zaproponowanych przez różnych autorów. Wyniki te nie są zbieżne, co potwierdza tezę o konieczności indywidualnego określania wartości współczynników w aspekcie rodzaju gruntu, parametrów wiodących oraz lokalizacji. Ma to szczególne znaczenie w przypadku gruntów organicznych, charakteryzujących się wyjątkowo skomplikowaną budową szkieletu gruntowego, zależną od lokalnych warunków zalegania.

\section{Literatura}

[1] Azzouz, A. S., Baligh, M. M. \& Ladd, C. C.: Corrected field vane strength for embankments design. Journal of the Geotechnical Engineering Division, ASCE, 109, GTS, 1983, pp. 730-730.

[2] Bjerrum, L.: Embankments on soft ground. Proc. Spec. Conf. on Performance of Earth and Earth Structures, ASCE, Purdue University, Lafayette, 1972, pp. 1-54.

[3] Bjerrum, L.: Problems of soil mechanics and construction on soft clays. Proceedings of the 8th International Conference on Soil Mechanics and Foundation Engineering, Moscow, 1977, 3, pp. 111-159.

[4] Chandler, R.J.: The in-situ measurement of the undrained shear strength of clays using the field vane. Vane Shear Strength Testing in Soils: Field \& Lab Studies, STP 1014, ASTM, West Conshohocken, 1988, pp.13-44.

[5] Edil, T.B.: Site characterization in peat and organic soils, Proc. Int. Conf. on In Situ Measurement of Soil Properties and Case Histories, Bali, Indonesia, 2001, pp. 49-59.

[6] Frankowski Z.: Interpretacja wyników sondowań dynamicznych i badań presjometrycznych. Materiały Seminarium: Nowoczesne metody badań gruntów, ITB, Warszawa, 2003, s.11-22.

[7] Hansbo, S.: A new approach to the determination of shear strength of clay the fallcone test. Stockholm: Royal Swedish Institute, 1957, Proc. No. 14.

[8] Hansbo S.: Foundation Engineering. Developments in Geotechnical Engineering, Elsevier, Amsterdam- London - New York - Tokyo, 1994.

[9] Jaremski J., Straż G.: Wstępne badania parametrów wytrzymałościowych torfu $\mathrm{z}$ rejonu Mielca z wykorzystaniem sondy PZO-1. Geologos, nr 11, Puszczykowo, 2007, s.201-209. 
[10] Jonsson M., Sellin C.: Correction of shear strength in cohesive soil. A comparison focused on vane tests in west Sweden. Master of Science Thesis in the Master's Programme Geo and Water Engineering, Göteborg, Sweden, 2012.

[11] Kulhawy F.H., Mayne P.W.: Manual on Estimating Soil Properties for Foundation Design, Final Report, EL-6800, Project 1493-6, Cornell University, Ithaca, New York, 1990.

[12] Ladd, C. C., Foott, R.: Foundation Design of Embankments on Varved Clays, U.S.Dept. of Transportation, FHWA TS-77-214, Washington, 1977.

[13] Landva A.O., La Rochelle P. (1983). Compressibility and shear strength characteristics of Radforth Peats, Testing of Peats and Organic Soils, ASTM STP 820, P.M. Jarrett (ed.), pp. 157-191.

[14] Larsson, R., Ahnberg, H.: Long-term effects of excavations at crests of slopes. Swedish Geotechnical Institute, Report No 61, Linköping, 2003.

[15] Larsson, R., Bergdahl, U., and Eriksson, L.,: Evaluation of Shear Strength in Cohesive Soils with Special Reference to Swedish Practice and Experience. Geotechnical Testing Journal, 1987, Vol. 10, No. 3, pp. 105-112, https://doi.org/10.1520/GTJ10942J.

[16] Mesri, G. and Ajlouni, M.: Engineering properties of fibrous peats. Journal of Geotechnical and Geoenvironmental Engineering, ASCE, 2007, 133(7), pp. 850-866.

[17] Morris, P.H. \& Williams, D.I.: A new model of vane shear strength testing in soils. Geotechnique 44, No. 4, 1994, pp.771-773.

[18] Ortigao J.A.R., Collet B.: Errors Caused by Friction in Field Vane Tests. Editor: Richards A.F. Vane Shear Strength Testing in Soils: Field and Laboratory Studies, ASTM International, 1998, STP 1014, pp.104-117.

[19] PN-B-02480:1986. Grunty budowlane. Określenia, symbole, podział i opis gruntów.

[20] PN-B-04452:2002 Geotechnika. Badania polowe

[21] PN-EN 1997-2: 2009. Eurokod 7. Projektowanie geotechniczne. Część 2. Rozpoznanie i badanie podłoża gruntowego.

[22] PN-EN ISO 14688-1:2006 Badania geotechniczne. Oznaczanie i klasyfikowanie gruntów. Część 1: Oznaczanie i opis.

[23] PN-EN ISO 14688-2:2006 Badania geotechniczne. Oznaczanie i klasyfikowanie gruntów. Część 2: Zasady klasyfikowania.

[24] Straż G.: O niektórych problemach związanych z określaniem parametrów geotechnicznych rzeszowskich gruntów organicznych. Badania i analizy wybranych zagadnień z budownictwa, J. Bzówka (Ed.), XI Konferencja Naukowa Doktorantów Wydziału Budownictwa, Gliwice-Szczyk, 2011, s. 143-149.

[25] Straż G.: Parametry wytrzymałościowe rzeszowskich namułów i torfów. Oficyna Wydawnicza Politechniki Rzeszowskiej, Rzeszów, 2011.

[26] Tarnawski M.: Nowe parametry oceny nośności podłoży organicznych. Prace naukowe Politechnki Szczecińskiej. Nr 17, Szczecin, 1989, s. 145-158.

[27] Terzaghi, K., Peck, R.B., Mesri, G.: Soil Mechanics in Engineering Practice. 3rd edition, John Wiley \& Sons, New York, 1996. 


\section{DETERMINATION OF UNDRAINED SHEAR STRENGTH OF SELECTED ORGANIC SOIL ON THE BASIS OF FVT TEST}

\section{S u m m a r y}

This paper presents the procedures and results of the estimation of undrained shear strength for selected organic soil located in the area of Rzeszow. The results of "in situ" tests performed with the FVT rotary probe were used for this purpose. The study showed that undrained shear strength values derived directly from field measurements are overestimated with respect to the results of alternative laboratory tests. The overview of the selected scientific literature was done in order to analyze the problems related to the need to correct the results obtained for the geotechnical aims by using of correction factor $\mu$. The paper suggest the proper value of the factor $\mu$, appropriate only for the analyzed organic soil. The value of undrained shear strength obtained by this method was compared with those given by other researchers.

Keywords: organic soils, undrained shear strength, Field Vane Test

Przestano do redakcji: $22.06 .2017 \mathrm{r}$.

Przyjęto do druku: 01.09.2017 r. 